\title{
Erratum to: 3D Modeling of Saline Groundwater Flow and Transport in a Flooded Salt Mine in Stassfurt, Germany
}

\author{
Junfeng Luo • Hans-Jörg G. Diersch • \\ Lambertus M. M. Monninkhoff
}

Published online: 19 December 2012

(c) Springer-Verlag Berlin Heidelberg 2012

Erratum to: Mine Water Environ (2012) 31:104-111

DOI 10.1007/s10230-012-0181-9

The authors would like to correct errors in the original publication as detailed below.

The correct version of the figure captions is given here:

Fig. 1 Location of project area Staßfurt (modified after Diersch et al. 2010)

Fig. 2 Geological profile (modified after Diersch et al. 2010)

Fig. 3 Exemplary result of reduced porosity caused by chemical reactions and precipitation (modified after Diersch et al. 2010)
The following reference has to be added to the reference list:

Diersch H-J, Luo J, Rühaak W (2010) Numerische Strömungs- und Massentransportmodellierung im Bereich des ehemaligen Kalibergbaus Staßfurt [Numerical modeling of flow and mass transport in the region of the abandoned Staßfurt salt mine]. Exkurs f und Veröffentl DGG 244:179-188

The online version of the original article can be found under doi:10.1007/s10230-012-0181-9.

J. Luo $(\bowtie)$ · H.-J. G. Diersch

DHI-WASY GmbH, Waltersdorfer Str 105,

12526 Berlin, Germany

e-mail: jlu@dhi-wasy.de

L. M. M. Monninkhoff ( $\square$ )

Hohai University, Xikang Rd,

Nanjing 210098, People's Republic of China

e-mail: bmo@dhi-wasy.de 